\title{
THE EVALUATION OF BOBBY BOLA DAN PERI BUKU AJAIB 3 FOR LANGUAGE LEARNING
}

\author{
Rika Hendryani \\ Email: ourstories2018@gmail.com
}

Petra Christian University, Indonesia

\begin{abstract}
Video games have received much attention in recent years as a tool for foreign language learning. A number of research have shown the positive impact of video games on language learning learners. This current study aims to find out the extent to which Bobby Bola \& Peri Buku Ajaib 3 meets the 10 principles for designing video games for foreign learning proposed by Purushotma, Thorne, and Wheatley (2009). The findings show that Bobby Bola \& Peri Buku Ajaib 3 adheres only to two principles, i.e., the principles of "communication and input mechanism should have a playful spirit to them" and "students should be allowed to spend extra time in activities they enjoy and to minimize time in ones they don't". The result of this study hopefully would be beneficial to the studies of video games for foreign language learning. It is also hoped that it can provide further information for those who wants to evaluate or use video games as a language learning tool.
\end{abstract}

Keywords: Educational Video Games, Language Learning

\section{INTRODUCTION}

Over the last decade or so, people can easily gain access to learning through the use of technologies. One that has been an object of interest in the last few years is language learning through video games. Video games are defined as "games played on game platforms (such as Sony PlayStation 2, the Nintendo GameCube, or Microsoft's Xbox) and games played on computers" (Gee, 2003, p.1). There are studies that have argued on the positive impacts of video games to the players' level of English. Video games have been shown to motivate student (Huang, 2011), to encourage greater time-on-task (Gee, 2003), and to increase learners' "Willingness to Communicate (WTC)" (Reinders and Wattanna, 2014, pp.101-102).

In recent years, some video games for foreign language learning have been developed in Indonesia; and one of them is Bobby Bola \& Peri Buku Ajaib 3. The video game was developed for 9 to 12 year-old children by PT. MISI (Edu-Games, 2017). The players play the role of Bobby Bola, a talking yellow ball eager to study English. They are able to learn English in the fairy's house through playing a total of 11 games. These games can develop the players' understanding of time, cardinal and ordinal numbers, family, friends, traffic light, the system of units, present tense, past tense, present continuous tense, future tense, wind direction, and public places in English (2017). 


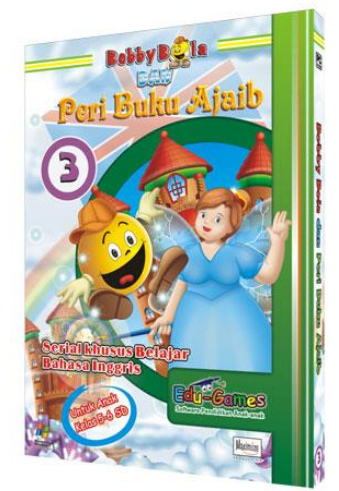

Figure 1. Cover of Bobby Bola dan Peri Buku Ajaib 3 (Edu-Games, 2017)

To help the players achieve the benefits of learning through video games, it is essential that the design of video games is appropriate for learning a foreign language. To this, Purushotma, Thorne, and Wheatley's (2009) have proposed 10 key design principles that should be used as a guideline for game developers in developing video games for language learning. The 10 key design principles are presented in the following list.

Table 1. List of 10 Design Principles for Foreign Language Learning Video Games

1. At least as much thought needs to go into the design of failure states as for success states.

2. Instruction needs to ensure that learners focus predominantly on meaning; secondarily, however, instruction should still include focus on form.

3. All elements of the game, particularly communication and input mechanisms, should have a playful spirit to them.

4. Metalinguistic descriptions and terminology should be presented through optional supporting material, not as part of the core gameplay.

5. Learning content should be organized around tasks, not presented taxonomically.

6. New concepts should be introduced gradually and interspersed with other content before requiring difficult responses from players.

7. Assessment should intelligently track free production tasks throughout the game, not simply measure controlled production during test events.

8. Consider the full range of gaming platforms available.

9. Games should allow students to spend extra time in activities they enjoy and to minimize time in ones they don't. Ultimately, instructional activities should be designed to teach students how they can autonomously continue playing similar games or performing similar activities taken directly from the target culture.

10. Where possible, multiplayer games should provide players with meaningful and distinct roles.

This study was done to find out to what extent Bobby Bola dan Peri Buku Ajaib 3 meets the principles for designing video games for foreign learning proposed by Purushotma, 
Thorne, and Wheatley (2009) as it is important to ensure that the designed game adheres to the principles for designing language learning game. In addition, it is worth noting that in Indonesia, to my knowledge, there has not been any study published in reputable journals examining the underlying design principles of creating video games for English language learning. There are some studies on the impact of video games to English language classroom (see Putri, 2015 for an example) and studies on how to develop video games for English language learning (see Adisti, 2016 for an example); but none looks into the underlying principles of the video games design. This lack of study inspired the researcher to conduct the present study focusing on the evaluation of the key principles found in 2 video games for English language learning.

\section{METHOD}

This study used qualitative approach specifically content analysis of video game evaluation. The main data of the present study is obtained from the video game Bobby Bola dan Peri Buku Ajaib 3. The data were collected through my personal experience in playing Bobby Bola dan Peri Buku Ajaib 3, which took approximately 3 hours to play.

The data analysis was based on the theory proposed by Purushotma, Thorne, and Wheatley (2009) on the 10 key principles for designing video games for foreign language learning.

\section{FINDINGS AND DISCUSSION}

This study revealed that Bobby Bola dan Peri Buku Ajaib 3 has covered 2 out of 10 principles for designing foreign language learning video games proposed by Purushotma, Thorne, and Wheatley (2009). The details are provided below.

\section{Principle \#1}

At least as much thought needs to go into the design of failure states as for success states.

As a learner of a new language, it is normal for the players to make mistakes and fail. What is important is how video games react to the failure that occurs. The designer of video game for foreign language learning should design games that not only give feedback, but also make failure part of fun in learning.

In Bobby Bola dan Peri Buku Ajaib 3 the design of both the success and failure states are similar. In general, there are two responses, which are sound and visual responses. The sound response is in the form of voice-over by the fairy that the players can immediately hear when they succeed or fail. The visual response is provided in several games only, and it is in the form of playful animation that notifies the players on whether their answer is correct or not. 
In the success states, the sound responses that the players receive are voice-over of the fairy congratulating, praising, and inviting them to play again in Indonesian. The responses given are for example, "Kamu pintar sekali!" (You are very smart!) or "Jawabanya benar!" (The answer is correct!). The visual responses are different depending on the games. In the Time Pendulum game, the players have to arrange the provided words into a sentence that expresses the correct time shown on a cuckoo clock. When the players have arranged the words correctly, an animated cuckoo bird will come out and give the players thumbs up. Furthermore, when the players succeed more than 3 times, the fairy will give a flag as a reward.

In the failure states, the sound response is the voice-over of the fairy notifying that the players have made a mistake and encourage them to try again. Two examples of the comments are, "Ini sudah salah. Ayo coba periksa kembali jawaban kamu" (This is incorrect. Come on, try to check your answer) or "Jawabanya sudah salah." (The answer is incorrect). In addition, there is also visual response, for example in the Time Pendulum game. In this game, an animated cuckoo bird will come out and give a disapproving head shake when the players answer incorrectly.

The design of the responses in Bobby Bola dan Peri Buku Ajaib 3 seems to be the common response that any video games would have for success and failures states, such as acknowledging the players' success or failure and saying encouraging words for them to try again. One problem is that it does not provide feedback such as, pointing out the mistakes or giving out suggestions to fix the mistake. This can be clearly seen in the Word Bomb game, in which the players need to complete a sentence by choosing bombs that each represents a letter in the alphabet. There are only 9 chances to choose the correct bombs. When the players fail, a voice-over by the fairy can be heard. Afterward, the players will receive a new sentence to complete without receiving any feedback for the former question.

Purushotma, Thorne, and Wheatley (2009) state that "good game design offers us the ability to form powerful learning experience out of mistakes" (p. 9). However, as can be seen from the example above, the design of the failure responses in Bobby Bola dan Peri Buku Ajaib 3 makes it unlikely for the players to learn and fix their mistakes. Errors are just dismissed and replaced with a new question. In such case, feedbacks should be provided. Creative feedbacks are particularly needed because such feedback "can be unbashfully explicit yet humorous and playful enough to actually have a positive impact on the learner's experience when they 'make mistakes' (Ravaja, et al., 2004 as cited in Purushotma, Thorne, \& Wheatley, 2009). An example of creative feedback is by showing a playful animation that points out mistakes and their correct answer.

\section{Principle \#2}

Instruction needs to ensure that learners focus predominantly on meaning; secondarily, however, instruction should still include focus on form. 
Video games for foreign language learning should be designed focusing more on meaning rather than form. By doing so, the players will be able to learn in context and not simply memorized various language elements.

Bobby Bola dan Peri Buku Ajaib 3 has a total of 11 games. 9 of the games are focused on form. The Caterpillar Letters game, for instance, requires the players to navigate a caterpillar in a square area. The players are given two pictures that each describes an adjective. The task is to collect letters scattered in the area to form the correct adjectives. The game can be categorized as a form-focused game because it only focuses on word spellings.

One problem with such game is that it does not help the players understand the meaning and context of how to use the word (Purushotma, Thorne, \& Wheatley, 2009). According to Renandya (2013), "the key thing to remember is that our students need to develop an in-depth knowledge of what these words mean and how to use them appropriately in a variety of contexts" (p.30). Therefore, the game should add an activity that gives the players a chance to develop their in-depth knowledge, such as differentiating the meaning of a word in different sentences.

Aside from the 9 form-focused games, there are also 2 games that focused more than form, namely Relaxing Cycling game and Navigation game. The Relaxing Cycling game is about learning traffic signs and lights in English. The players' task is to navigate the character Bobby Bola that is riding his bicycle on the road. For every traffic sign that passes, the players have to answer a multiple-choice question of what the sign means. This activity is a form-focused activity because the game only questions the definition of the traffic signs, but does not put attention to its contexts of use. Furthermore, in the game, the players have to abide the traffic light rules (stop at red and go at green). By doing so, they learn the traffic light rules and how it applies in the situation. The Relaxing Cycling game, thus, has both focused on form and meaning activity.

The Navigation game is about learning wind direction and signs of public places. The players' task is to guide Bobby Bola to the correct public place sign by arranging three directional orders such as (1) 4 squares to North, (2) 3 squares to South West (3) 2 square to West. This makes the activity meaning-focused that require the players' knowledge of wind direction. They are not simply asked to click where North or West is.

Overall, Bobby Bola dan Peri Buku Ajaib 3 mainly consists of focused-on form activity. Out of 11 , only 2 games that have focused on meaning activity. The result might be due to the age of the target players that are still young and need more practice on mastering the basic form of English. Renandya (2013) suggests that learners of language need to have at least the basic structure of grammar and plenty exposure to vocabulary before they can produce comprehensible language. 


\section{Principle \#3}

All elements of the game, particularly communication and input mechanisms, should have a playful spirit to them.

Communication and input mechanism in video games for foreign language learning should be designed to let the players construct statements rapidly, with consciously thinking of how to construct the statements at the same time.

The majority of the games in Bobby Bola dan Peri Buku Ajaib 3 are on sentence construction, by which the players have to arrange words into sentences. These games only require the players to click and/or drag the mouse to answer. For example, the Mechanical Wheels game task is to arrange jumbled words into the correct simple tense sentence. To do so, the players need to click the words given using the mouse and drag them to the boxes in the conveyor belt provided.

In addition, the Caterpillar Letters and Relaxing Cycling game are two games that do not use the mouse but require them to use the arrow keys on the keyboard to play. The Caterpillar Letters games task is to navigate a caterpillar around an area to collect letters that ultimately form two adjectives. The Relaxing Cycling game task is to navigate Bobby Bola, the character of the game, that is riding a bicycle on the road. In this game, paying attention to traffic signs and the traffic light is crucial.

The mechanism to input answer in Bobby Bola dan Peri Buku Ajaib 3's game is quite rapid. This is because, first, the games prepare items (e.g. words, letters, and pictures) to answer the questions given, instead of expecting the players to construct their own output. Second, the mechanism to answer and carry out the task in the games only use two input devices, i.e., mouse and keyboard's arrow keys. The players do not have to type out their own answer, which can be "too slow and cumbersome for use in a video game" (Purushotma, Thorne, \& Wheatley, 2009, p. 12).

There is a concern that learning of language form may not happen when construction of language is not performed by the players (2009). To this, the findings show that learning of language form still take place although construction does not take place. The games do not require the players to create their own sentences, but they will learn language forms by thinking of all the steps in the construction. For example, in the Mechanical Wheels game, the players have to think of how to arrange the words into sentences since there is no list of preconstructed sentences to choose from.

In terms of communication mechanism (e.g., voice or speech recognition system), Bobby Bola dan Peri Buku Ajaib 3 does not have one. One possible reason is because the game focuses on giving input for its young players (9 to 12 years old) that are still in the early stage of learning English. This is what Renandya (2013) highlights in his paper. He believes that EFL learners with low proficiency level still need to strengthen their linguistic base so that later they will be able to comprehend and produce language on their own. Therefore, they 
should not be forced to speak and write language when they are not prepared to do so (2013).

\section{Principle \#4}

Metalinguistic descriptions and terminology should be presented through optional supporting material, not as part of the core gameplay.

Designer of foreign language learning should not create a game that needs the players to give metalinguistic descriptions or terminology in order to succeed. In contrast, game should focus more on accomplishing meaningful tasks.

The games in Bobby Bola dan Peri Buku Ajaib 3 do not demand the players to describe metalinguistic concepts or to name metalinguistic terms. However, they do need metalinguistic knowledge to succeed in the games. Bobby Bola dan Peri Buku Ajaib 3 prepares the players by providing them short grammar lectures ( $2-10$ minutes) before playing each game. In general, the short lecture provides the players with definition, sentence pattern, and examples of specific grammar points. It is worth noting that the lecture is compulsory and cannot be skipped. The players can only skip after listening to it once. Thus, explanation of metalinguistic description and terminology is part of the core gameplay instead of supporting material.

The result is contrary to this $4^{\text {th }}$ principle, in which it explains that grammar terms and language structure should be available, but at the same time separate from the actual gameplay space (Purushotma, Thorne, \& Wheatley, 2009). However, the decision to put the lecture as the core game play might be based on the thoughts that the target players of Bobby Bola dan Peri Buku Ajaib 3 are young learners. As stated by Swan (2002), learners of English in their early stage of proficiency still need to study the basic grammatical structures (i.e., basic sentence structure, basic verb forms, the main tenses, and the use of modals) to improve their comprehensibility (Renandya, 2013).

\section{Principle \#5}

Learning content should be organized around tasks, not presented taxonomically

The learning content in Bobby Bola dan Peri Buku Ajaib 3 is not organized around task, but grouped taxonomically. The result may be correlated with two things. First, the video game has no major goal or task that the players need to achieve. The players' task is to play and practice succeeding in the games. Also, it is worth noting that the games are not interrelated because each game teaches different point or topic of discussion. The Penalty Kick game, for instance, teaches about food partitive only. In this game, the players' task is to click on the partitives that match the picture given. For example, if they are given a picture of a bread, the correct answer would be by clicking the partitive 'a loaf of'.

Second, it might also be because the games in Bobby Bola dan Peri Buku Ajaib 3 are form-focused rather than meaning-focused. The games are form-focused because they emphasized on memorization of grammar sentence structure and vocabulary. Games that 
focused on form do not organize the learning content around task, since the attention is on linguistically based goals (Purushotma, Thorne, \& Wheatley, 2009).

Learning form-focused games taxonomically have its benefits, especially in practicing grammar structure and vocabulary that the players have learned before. Anderson et al., and Vercoe (2006) comment that learning through taxonomical grouping is beneficial when used as a review (as cited in Purushotma, Thorne, \& Wheatley, 2009). In addition, having formfocused games is helpful for the players in the early phase of learning that still need to pay close attention to linguistic accuracy. To this, Renandya (2013) states that linguistic accuracy should not always be ignored. Grammar and vocabulary errors are harder to see in games that are organized around tasks; since such task often ignore linguistic errors (Nishimura, 2000). Therefore, in video game such as Bobby Bola dan Peri Buku Ajaib 3 that is design for early learners of English, it might be good to learn through playing form-focused games taxonomically.

One challenge of using such system is that the players might have difficulty in fully developing their vocabulary. If the players are taught through taxonomical grouping, they will likely learn the basic meaning of the words without understanding the diverse meaning of words in different context. The Caterpillar Letters game, for example, ask the players to collect letters to create two adjectives that describe the two picture given. This game only focuses on learning and practicing the basic meaning and spellings of adjectives. The players do not have the chance to use the adjectives in different sentences or situations. It is actually essential that learners have an awareness of how to use the words in various contexts and also an in-depth knowledge of the different meanings a word can have (Renandya, 2013).

\section{Principle \#6}

New concepts should be introduced gradually and interspersed with other content before requiring difficult responses from players.

Video games for foreign language learning should allow the players to progress from one stage to the other when they are ready to do so. Designers could introduce language concepts using various task throughout the game. These tasks should guide the players first and progressively requires the players to produce when they are ready.

Bobby Bola dan Peri Buku Ajaib 3 does not have levels or stages in its design. This is likely because the video game is the third volume of the Bobby Bola dan Peri Buku Ajaib series. Therefore, the level of difficulty is divided based on the volume. This means that all the games inside the volume have the same level of difficulty. It also means that concepts are not introduced gradually through levels, but inside each volume. The third volume teaches the players about time, cardinal and ordinal numbers, family, friends, traffic light, system of units, present tense, past tense, present continuous tense, future tense, wind direction, and public places in English (Edu-Games, 2017).

Since there is no level in Bobby Bola dan Peri Buku Ajaib 3, the players have the advantage to pick and play the games they want repetitively. According to Purushotma, 
Thorne, and Wheatley (2009), letting the players control their choices and actions may increase their interest in learning the language. However, since there is no level in this volume, concepts are not gradually introduced and shared among various tasks. There is only one level and each game inside has different tasks and presents different points of discussion.

One concern of such game design is that the players may find it hard to master the concepts taught in the games. As stated by Doughty and Long (2003), "The idea what you teach is what they learn, and when you teach it is when they learn it, is not simplistic, but wrong..." (as cited in Purushotma, Thorne, \& Wheatley, 2009, p.20). Although they might be able to memorize enough concepts to pass tasks in the games, the knowledge is unlikely to enter their 'interlanguage' and will ultimately be forgotten not long after (2009).

It might be better if the mechanism does allow the players to learn concepts through various tasks that steadily require more difficult forms of responses. In doing so, "we allow students to progress from each stage to the next as their internal system is ready to do so" (2009, p.20). Furthermore, as Renandya (2013) has suggested the players should practice more listening and reading activities that contain various, ample, comprehensible, and interesting input in order achieve better proficiency in English.

\section{Principle \#7}

\section{Assessment should intelligently track free production tasks throughout the game, not} simply measure controlled production during test events.

Assessment in video games should assess all the players' activities during the game, even when making mistakes. In addition, there should be a mechanism to recognize if the players are aware of their mistake to ensure that the players understand, although may still not be able to use it.

The players' progress in Bobby Bola dan Peri Buku Ajaib 3 is assessed through their results in playing the 11 games it provides. The players will receive a yellow flag when they succeed in playing a game number of times, commonly 3 times in a row. When the players managed to collect 30 yellow flags, it will turn into 1 bigger blue flag. These flags are a form of reward given by the game, which can be seen by clicking the blue flag icon on the main menu screen.

Moreover, there is also a progress chart that tracks and records the successes and failures of the players when playing the 11 games. The chart presents the percentage of success rates and the number of play time of each game. Unfortunately, it does not point out and give out details on areas that can be improved on. This makes it hard to distinguish which areas that the players should practice more. It is even harder to distinguish if they understand the material or not since there is no mechanism to detect whether they notice their mistake or not and whether they know what the correct answers should be.

Purushotma, Thorne, \& Wheatley (2009) believe that a mistake does not always mean failure, it could also be a sign of progress. Therefore, it is crucial to have a mechanism 
that is able to identify the players' awareness toward their mistake. By doing so, it makes it easier to distinguish the areas that the players need practice on. Schimdt (1990) claims that being able to recognize one's own mistake can help the process of language learning greatly (as cited in Purushotma, Thorne, \& Wheatley, 2009). This suggests that Bobby Bola dan Peri Buku Ajaib 3 might add a mechanism to keep assessing the players even when they make mistakes.

\section{Principle \#8}

\section{Consider the full range of gaming platforms available.}

The development of technology over the years has created numerous ways to play games, from putting coins on machines to tapping on cellphone. Designer of video game should select the most appropriate platform based on the strengths and weaknesses of each video game form.

Bobby Bola dan Peri Buku Ajaib 3 works only on computer with Windows 98/ME/ 2000/XP/Vista/7 operating systems. In addition, there is a CD program that needs to be installed in the computer before playing. Bobby Bola dan Peri Buku Ajaib 3 does not run on other gaming platforms or operating system.

The decision to choose computer as the gaming platform for Bobby Bola \& Peri Buku Ajaib 3 might be related to the fact that computer generally lets the players have better control over hardware and graphics than other gaming platforms. In addition, according to the 2016 annual research on the computer and video game industry by The Entertainment Software Association, computer is the most frequent device used for playing video games (ESA, 2016). However, it might be best if the developer of Bobby Bola dan Peri Buku Ajaib 3 update the game's operating system, especially since many computers nowadays run mostly on Windows 10.

\section{Principle \#9}

Games should allow students to spend extra time in activities they enjoy and to minimize time in ones they do not. Ultimately, instructional activities should be designed to teach students how they can autonomously continue playing similar games or performing similar activities taken directly from the target culture.

Considering the importance of the affective factors for learners, designers of foreign language learning game should design a game that let the players take in charge of their own learning. By doing so, the players might be interested in learning the language outside the game.

There are three game areas in Bobby Bola dan Peri Buku Ajaib 3. In each area, there are 4 to 5 games that are not in sequence. Therefore, the players have the upper hand to choose the game and spend time on it. Also, all the games can be played repeatedly. 
It is important to note that the players have to listen to a short lecture (2-10 minutes) before playing each game. This applies only when the game is played for the first time, it can be skipped afterward.

The key element of motivation is choice (Renandya, 2015). Therefore, allowing the players to pursue their interest by choosing the game that they enjoy will likely increase their motivation on language learning. In addition, it increases the possibility of learning language outside of Bobby Bola dan Peri Buku Ajaib 3 as stated by Purushotma, Thorne, and Wheatley (2009) 'by designing language learning games that adapt to students' agentive choices and actions, we have the potential continue their interest in learning the language far beyond the length of the game we develop" (p.24). Therefore, there might be a chance that they will play similar game or activity such as, spelling games and sentence structure games that can be found in Bobby Bola dan Peri Buku Ajaib 3.

\section{Principle \#10}

Where possible, multiplayer games should provide players with meaningful and distinct roles.

In multiplayer games, the players should be encouraged to collaborate with one another to create a more communicative learning. It is important to note that each player in the multiplayer games should be given individual role that is meaningful for the group.

Bobby Bola dan Peri Buku Ajaib 3 is a single-player game. The game is not designed to allow multiple players play simultaneously, although it does allow the registration of up to 3 separate player accounts.

The multiplayer feature is not available because the video game is designed for selflearning rather than communicative learning. The focus of the game is to practice on several points of English grammar and vocabulary by themselves.

This study shows that Bobby Bola \& Peri Buku Ajaib 3 has covered 2 out of 10 principles for designing foreign language learning video games proposed by Purushotma, Thorne, and Wheatley (2009). The results revealed that Bobby Bola dan Peri Buku Ajaib 3 met only 2 design principles, i.e. the 3rd and 9th principle. The 3rd principle is applied in the video game by having rapid input mechanisms to answer questions while still pushing the players to think of all the steps in constructing the answers. The 9th principle is shown through the mechanism of Bobby Bola dan Peri Buku Ajaib 3 that allows the players to decide their own learning and pursue their own interest by choosing the activities they want to play.

\section{CONCLUSION}

This study has investigated the extent of Bobby Bola dan Peri Buku Ajaib 3 meeting the principles for designing video games for foreign learning proposed by Purushotma, Thorne, and Wheatley (2009). The game has covered 2 out of 10 principles, i.e., the 3rd which is 
providing various, easy, rapid yet challenging input mechanisms of the answers and the 9th principle in which the game provides various options for the players to play the activities they wish to suit their own learning.

Based on the data analysis, I would like to suggest the game developers of Bobby Bola dan Peri Buku Ajaib 3 to improve the quality of their future video games. This can be done by integrating more principles proposed by Purushotma, Thorne, and Wheatley (2009). It is also recommended that further researcher to analyze the underlying principles of other educational video games, otherwise to conduct a longitudinal study to determine the effect of both educational and commercial video games on one's language acquisition can be undertaken. Furthermore, I hope that this study could be a starting point for further studies on video games for language learners at all age.

\section{REFERENCES}

Adisti, A.R. (2016). Creating an English computer game as an interactive material in teaching English to young learner (TEYL). Register Journal, 9(2), 4970. Retrieved March 2, 2017 from http://dx.doi.org/10.18326/rgt.v9i2.712

Edu-Games. (2017). Informasi. Retrieved February 7, 2017 from http://www.edugames.com/index.php?Ref= company

ESA. (2016). Essential Facts about the Computer and Video Game Industry. Retrieved May 18, 2017 from http:/ / essentialfacts.theesa.com/Essential-Facts-2016.pdf

Gee, J. P. (2003). What Video Games Have to Teach Us About Learning and Literacy. New York: Palgrave Macmillan.

Huang, W. H. (2011). Evaluating learners' motivational and cognitive processing in an online game-based learning environment. Computer in Human Behavior, 27(2), 694704

Nishimura, K. (2000). Effective ways of communicative instruction in the Japanese EFL classroom: Balancing fluency and accuracy. Retrieved February 21, 2017, from http: / files.eric.ed.gov/fulltext/ED442297.pdf

Purushotma, R., Thorne, S.L., \& Wheatley, J. (2008). 10 key principles for designing video games for foreign language learning. Retrieved 10 January, 2017 from http: / / pdxscholar.library.pdx.edu/cgi/viewcontent.cgi?article $=1008 \&$ context $={ }_{w} l l$ fac

Putri, Y.K. (2015, September). Using video games to improve students' writing ability. Paper presented at the $62^{\text {nd }}$ TEFLIN International Conference Teaching and Assessing L2 Learners in the $21^{\text {st }}$ Century, Denpasar. Indonesia: Udayana University Press.

Reinders, H., \& Wattana, S. (2014). Can I say something? The effects of digital game play on willingness to communicate. Language Learning \& Technology, 18(2), 101-123.

Renandya, W.A. (2013). Essential Factors Affecting EFL Learning Outcomes. English Teaching, 68(4), 23-40.

Renandya, W.A. (2015). L2 motivation: Whose responsibility is it? English Language Teaching, 27(4), 177-189. 


\section{ACKNOWLEDGMENT}

I would like to thank Bu Flora Debora Floris of Petra Christian University for her academic support. This paper was based on some parts of my unpublished thesis submitted to Petra Christian University, Surabaya (Indonesia). The very first draft of some parts of this paper was presented at The 5th Undergraduate Conference on ELT, Linguistics, and Literature conference organized by English Language Education Study Program, Sanata Dharma University, Yogyakarta. 